\title{
Standardization of a quantification method for Salmonella spp. and Shigella spp. in specific liquid media
}

\author{
Sandra Patricia Rivera, B acteriol ${ }^{1}$, Liliana Janeth Flórez, Statist², \\ Janeth Sanabria, M ICrobiol, $P_{\text {h }}{ }^{1}$
}

\section{SUMMARY}

Introduction: Chlorination is the most widely used disinfection process for drinking water production. The formation of chlorination carcinogenic by-products and chlorine intoxication by direct manipulation in small communities has motivated the study of alternative disinfection processes. In this sense, processes of advanced oxidation (PAOs) have yielded promising results. Escherichia coli (E. coli) is customarily used as faecal bacterial indicator to determine the efficiency of disinfection processes. However, it has been shown that E. coli is less resistant to disinfection than other enteric bacteria such as Shigella spp. and Salmonella spp. Additionally, the viable non-culturable (VNC) state yields bacteria which are not detectable on many culture media.

Objective: The main objective is to standardize a method for counting Salmonella spp. and Shigella spp. in specific liquid media to reliably quantify the bacteriological potential risk related to disinfection processes based on PAO.

Methods: The study followed a randomized bi-factorial experimental design and the Duncan multiple comparison test. This design allowed the selection of specific liquid media to fittingly standardize the counting of Salmonella spp. and Shigella spp.

Results: We found that the best broth for counting Salmonella typhimurium strain at different concentrations in pure and mixed cultures was the Rappaport broth RP, the EE broth also allowed growing the two bacterial species tested in this research. Nonetheless, the latter results suggest the use of additional tests for this particular broth.

Discussion: There was a variation in the counting results when pure cultures were used compared to those obtained from mixtures of microorganisms. It was also noted thatSalmonella typhimurium and Shigella sonnei, were recovered from minimal concentrations in both RP and EE broths, respectively. To some extent, this suggests an additional confirmative method when using the $\mathrm{EE}^{\circledR}$ broth.

Conclusion: MPN is a rapid and inexpensive method; easy to apply in water and other contaminated environments where counting of Shigella spp. and Salmonella spp. is needed to estimate potential bacteriological risks. The broths selected were able to recover the two bacterial species from densities as low as 10 cells per $100 \mathrm{ml}$.

Keywords: Bacterial quantification; Shigella spp.; Salmonella spp.; Most probable number (MPN); Advanced oxidation process; Faecal pollution indicators.

\section{Estandarización de un método de recuento para Salmonella spp. y Shigella spp. en medios de cultivo líquidos} especializados

\section{RESUMEN}

Introducción: La cloración es el método más usado para desinfectar aguas de consumo. La formación de subproductos cancerígenos y las intoxicaciones por manipulación directa en pequeñas comunidades, han motivado el estudio de procesos alternativos. Los procesos de oxidación avanzada (PAOS), han arrojado resultados prometedores, utilizando el indicador bacteriano Escherichia coli (E. coli), con el método recuento en placa. Sin embargo, también se ha demostrado que E. coli es menos resistente a la desinfección que otras bacterias entéricas como Shigella y Salmonella y que estos procesos generan bacterias viables que no se cultivan durante el proceso, y no se descubren en medios sólidos.

1. Research Group on Advanced Oxidation Processes, School of Engineering of Environmental and Natural Resources, Universidad del Valle, Cali, Colombia. e-mail: sandrapatriciarivera82@gmail.com_sanabria@univalle.edu.co

2. MSc candidate in Epidemiology, School of Public Health, Universidad del Valle, Cali, Colombia. e-mail: liflorez27@ hotmail.com Received for publication August 20, 2009 Accepted for publication January 12th, 2010 
Objetivo: Estandarizar un método de recuento de Salmonella sp. y Shigella sp., en medios de cultivo líquidos especializados, que permita valorar de forma confiable el riesgo bacteriológico en procesos de desinfección PAOS.

Métodos: En el presente trabajo se ensayaron y seleccionaron medios líquidos especializados, con los que se estandarizó el recuento de Salmonella sp. y Shigella sp., mediante un diseño experimental aleatorizado bifactorial y la prueba de comparaciones múltiples de Duncan.

Resultados: Se encontró que el mejor caldo para recuperar a $S$. typhimurium a diferentes concentraciones, en cultivos puros y mezclas, fue el caldo Rappaport de Merck (RP). El caldo de enriquecimiento para entero bacterias de Oxoid (EE), permitió un buen crecimiento de las dos especies objeto de esta investigación. Lo cual sugiere el empleo de pruebas adicionales cuando se use caldo EE para NMP.

Discusión: Se observó una variación en el recuento cuando se usaron cultivos puros, comparado con la obtenida a partir de mezclas de microorganismos. Sin embargo, $S$. typhimurium. y Shigella sonnei logran ser recuperadas de concentraciones mínimas en los caldos RP, respectivamente.

Conclusión: Se pudo estandarizar un método de fácil aplicación a aguas y otros ambientes contaminados para recuento de Salmonella sp y Shigella sp. Los medios líquidos seleccionados fueron capaces de recuperar concentraciones de menos de 10 bacterias.

Palabras clave: Cuantificación de Shigella spp.; Salmonella spp.; Número más probable (MPN); Proceso de oxidación avanzada; Indicadores de contaminación.

As a result of human activities and of the accelerated demographic growth, progressive deterioration of the quality of natural sources of water has been generated; this propitiate the development of an important diversity of pathogenic organisms, including viruses, bacteria, protozoa, fungi, and parasitic worms that represent risks, especially for rural communities where the coverage and quality of potabilization services is defficient ${ }^{1}$. Disinfection processes are not always present in waters consumed by these communities and in instances where they do exist; there are difficulties in the access to the disinfecting agent, in its storage, manipulation, and in the lack of technical capacity to carry out the process ${ }^{2}$. Disinfection with chlorine, also presents the risk associated to the generation of toxic compounds or disinfection by-products (DBPs) as a result of its reaction with the organic matter present ${ }^{3}$, consequently, interest has been generated to reduce the chronic effects of these types of compounds without compromising the microbiological safety of the water ${ }^{4}$ and different alternatives to disinfecting with chlorine have been explored, as are: solar radiation, electrochemical disinfection, ozonization, and advanced oxidation processes (AOPs) $)^{5}$. AOPs are processes involving the generation of highly oxidizing species often called reactive oxygen species (ROS), as for example hydroxyl radicals $(\bullet \mathrm{OH})$ with higher oxidation potential $(\mathrm{E}=2.8 \mathrm{~V} v s$. NHE). This radical can be generated through photochemical means (UV and solar light) or through other forms of energy, and it is highly effective for the oxidation of organic matter ${ }^{6}$. Organic compounds are mainly oxidized through abstraction of hydrogen or by electrophilic addition to double bonds generating free organic radicals $(\mathrm{OR})$ that react with oxygen molecules forming a peroxy-radical, initiating a series of oxidative degradation reactions that can lead to the thorough mineralization of the contaminants ${ }^{7}$. For the specific case of microorganisms, it has been reported that these radicals attack the double bilipid layer that makes up the outer cell wall generating reactions of lipid peroxidation that are lethal for microorganisms ${ }^{8}$. Photo-catalysis bears economic and ease-of-handling advantages given that it utilizes solar energy for the elimination of chemical compounds and inactivation of microorganisms ${ }^{5}$. Because E. coli and the Coliforms group are the models of greater application for the estimation of the microbiological quality of the water under current regulations, numerous disinfection results with photo-catalysis have been published basing the conclusions on studies with these bacteria, using the quantification method on solid media. It has been shown that these processes can generate nonculturable viable bacteria, which can reactivate hours after treatment ${ }^{9}$. Furthermore, it is evidently important to prove the effectiveness of the process in other pathogens that could be more resistant to disinfection by using PAOs ${ }^{10}$. S. typhimurium and Shigella sonnei have important implications as causal agents of acute diarrheic illness (ADI). A study developed in 18 departments of Colombia, between January 2000 and December 2001, found an important incidence of ADI related to these bacteria ${ }^{11}$; additionally, in the department of Valle del Cauca, contamination of natural water sources has been observed with Salmonella and Shigella, and patients diagnosed with ADI have had these bacteria. There are no methods developed to quantify the genre of Salmonella spp. and Shigella 
spp.; the methods available are applications to determine the presence or absence of the pathogens in a sample volume or quantification on plate in media like SS. Notwithstanding the great variety of products commercially available, the percentages of recovery may vary for the different formulations. Bearing this in mind, we consider it important to quantify these bacteria to evaluate the effectiveness of disinfection in the photo-catalysis process. The quantification with MPN has the advantage of favoring the growth of stressed cells and contributing a better reference of the process of disinfection with photo-catalysis ${ }^{12}$, this technique permits establishing populations with ranges $<3 \mathrm{CFU}$ $\mathrm{mL}^{-1}$, using relatively large sample volumes. The objective of the current work consisted in standardizing a lowcost methodology, based on the quantification technique with MPN to detect populations of Shigella spp. and Salmonella spp. The table of probabilities was obtained of MPN for Salmonella in Rappaport broth (Merck) and EE broth (Oxoid) for Shigella. A variation was observed in the quantification when pure cultures were used compared to those obtained from mixes of bacteria from different species. The liquid media selected were able to recover concentrations of less than 10 bacteria.

\section{METHODS}

Bacterial strains. For the study, ATCC reference strains were used; Salmonella typhimurium ( $S$. typhimurium) 15,490 serovariety, Shigella sonnei ( $S$. sonnei) 25,931, Escherichia coli (E. coli) 23,716, and Staphylococcus aureus (S. aureus) 6,538. For productivity and selectivity, Klebsiella pneumoniae (K. pneumoniae) was also used, isolated from clinical specimens at Hospital Universitario del Valle, confirmed through biochemical tests in enterotubes (BBL II ref. 273,176), plastic tubes with compartments, formed by 12 different culture mediums, permitting the determination of 15 biochemical reactions.

Productivity and selectivity. In order to select the best culture broth to standardize the most-probablenumber technique (MPN), to quantify Salmonella spp. and Shigella spp., four culture broths were used for experimentation: Rappaport broth from Merck (RP), enrichment broth for entero bacteria (EE) -Oxoid, selenite-cystine (SC) broth from Merck, and tetrathionate (TT) broth from Difco, recommended in standard methods for these bacteria and used in Colombia.

Productivity tests. $100 \mu \mathrm{l}$ of bacterial suspension from each bacterial strain, was transferred to a tube with $10 \mathrm{ml}$ of nutrient broth (Oxoid), it was incubated for 18 hours at $35^{\circ} \mathrm{C}$. With cultures from the Shigella spp. strain or $S$. typhimurium in stationary phase, $\left(10^{8} \mathrm{CFU}\right.$ $\mathrm{ml}^{-1}$, adjusted with the MacFarland Standard at 0.5) scale, consecutive decimal dilutions $\left(10^{-1}\right.$ a $\left.10^{-10}\right)$ were prepared, with two repetitions, in peptonated water at $0.1 \%$. We seeded $1 \mathrm{ml}$ from each dilution in tubes with $10 \mathrm{ml}$ of the RP, EE, SC, and TT media; the tubes were incubated at $35^{\circ} \mathrm{C}$. E. coli and S. aureus were used as control strains. The productivity of a selective culture broth should permit the development of a pure culture of the strain desired with an inoculate of 20 cells or less ${ }^{13}$; thus, the number of $\mathrm{CFU} \mathrm{ml} \mathrm{m}^{-1}$ was estimated from the last two positive dilutions taking $0.1 \mathrm{ml}$ to growth on plates of nutrient agar, Hektoen medium from Merck was used for $S$. sonnei, xylose-lysine deoxycholate (XLD) from Merck for S. typhimurium, incubated at $35^{\circ} \mathrm{C}$ for 24 hours.

Selectivity test. What is sought with this test is to determine the capacity of a culture medium to inhibit accompanying biota ${ }^{14}$. E. coli ATCC $23,716, S$. aureus ATCC 6,538, and $K$. pneumoniae strains were used in the study. $1 \mathrm{ml}$ of culture in stationary state of each of the microorganisms was transferred onto a test tube. From the mixture, a $10^{-2}$ dilution was prepared in peptonated water at $0.1 \%$. For the test strains $(S$. sonnei and S. typhimurium), 10 consecutive dilutions $\left(10^{-1}-10^{-10}\right)$ were done. In tubes with $10 \mathrm{ml}$ of each of the four culture mediums, RP, EE, SC, and TT, $0.2 \mathrm{ml}$ of the mixture and $1 \mathrm{ml}$ of each dilution of the test strains was seeded; it was incubated at $35 \pm 1^{\circ} \mathrm{C}$ between $18-24$ hours, the culture in SC was incubated at $44 \pm 1^{\circ} \mathrm{C}$. From $0.1 \mathrm{ml}$ of the 3 last positive dilutions and a negative dilution, the $\mathrm{CFU} \mathrm{m} \mathrm{m}^{-1}$ number was estimated in agar plates with Oxoid Nutrient, Hektoen from Merck, Levine eosin methylene blue agar EMB medium, and xyloselysine deoxycholate medium from Merck (XLD). The Petri dishes were incubated at $35 \pm 1^{\circ} \mathrm{C}$ for 24 hours. Quantification and biochemical tests were conducted on the resulting colonies in BBL enterotubes.

Interpretation parameters. For the qualitative and quantitative assessment of productivity and selectivity, we kept in mind the recommended parameters for international standards ${ }^{15}$ that were also employed in 
Table 1

Factors and levels of the randomized bi-factorial structure experimental design for the standardization of the MPN

\begin{tabular}{ll}
\hline \multicolumn{1}{c}{ Factors } & \multicolumn{1}{c}{ Levels } \\
\hline First factor: & Shigella sonnei in EE broth (A), Staphylococcus aureus. in EE broth \\
Microorganisms & (B), Mix. in EE broth (C), Escherichia coli in EE broth (D), Salmonella ser \\
& $\begin{array}{l}\text { typhimurium in Rappaport broth (E), Staphylococcus aureus. in } \\
\text { Rappaport broth (F), Mix. in Rappaport broth (G), Escherichia coliin } \\
\text { Rappaportbroth }(\mathrm{H}) .\end{array}$ \\
& $10^{1}, 10^{2}, 10^{3}$, and $10^{4}$ \\
\hline
\end{tabular}

Colombia. We compared turbidity and the quantification of CFU ml-1 $\geq 10$.

Standardization of the most probable number. The MPN technique was standardized for $S$. typhimurium and $S$. sonnei, taking as a model the protocols reported by the official Mexican norm, Nom004-Sermanat of $2002^{16}$, and by the MPN for E. coli according to standard methods of 2005, using liquid media RP and EE.

Experimental analysis. A randomized bi-factorial experimental design was used. The study considered 2 factors: A) Microorganisms that will comprise levels $S$. sonnei and S. typhimurium and the controls of the experiment; $S$. aureus (negative control), E. coli and a bacterial mixture composed of E. coli, S. sonnei, and $S$. typhimurium. B) The bacterial concentration, which comprises levels $10^{1}, 10^{2}, 10^{3}$, and $10^{4}$ for a total of 32 treatments (Table 1). The experimental units considered in this study are the test tubes with the broths chosen based on the results in the productivity and selectivity phase. For each test tube containing the different broths (RP and EE) different treatments are randomly assigned; S. typhimurium and S. sonnei and controls with their respective concentrations. With the results from the first 16 experiments of the MPN, representativeness of the sample size was analyzed. Finally, the probability tables were found according to Briones et al., based themselves on the data by deMan ${ }^{17}$. TheSPSS statistical package, version 10 of 2006, was used for data processing.

\section{RESULTS AND DISCUSSION}

Selection of culture media to standardize the MPN technique for S. typhimurium and S. sonnei. The MPN technique has been used over several years to quantify $E$. coli and other microorganisms. One of the most critical aspects of this method is the selection of reliable culture media, which permit the development of the desired microorganism, but inhibit the accompanying micro flora. For desired microorganisms the quantification should be around $10^{6} \mathrm{CFU} \mathrm{ml}^{-1}$ to $10^{8} \mathrm{CFU} \mathrm{ml}{ }^{-1}$. For undesired microorganisms, the count should not exceed $10^{4} \mathrm{CFU} \mathrm{ml} \mathrm{m}^{-1}$. Symbols were given (-) for negative turbidity and negative growth on plate $(+)$, for positive turbidity and positive growth. Commercially, there is no availability of dehydrated culture media that are selective for Shigella spp.; for this reason, measurements for these bacteria were complemented with biochemical tests.

The results are shown in Tables 2 and 3, noting that although the productivity of all the broths for the recovery of suspensions of S. typhimurium in pure culture is high, when in the presence of other microorganisms recovery may vary, the highest growth values were obtained in RP -this broth was productive and selective for $S$. typhimurium up to concentration $10^{9}$ - no growth of $S$. aureus was observed. Productivity of $S$. sonnei and $E$. coli were low in this culture medium.

In the SC broth, S. typhimurium productivity was high, growing in concentrations of $10^{9}$ bacteria per $\mathrm{ml}^{-1}$, but selectivity was low and high concentrations of 
Table 2

Results of productivity tests for sample bacteria (S. typhimurium, S. sonnei) and control bacteria

\begin{tabular}{|c|c|c|c|c|c|c|c|c|}
\hline & $\mathbf{R P}$ & SC & EE & $\pi$ & $\mathbf{R P}$ & SC & EE & Tा \\
\hline Liquid media & \multicolumn{4}{|c|}{ S. typhimurium } & \multicolumn{4}{|c|}{ S. sonnei } \\
\hline & & & & & & & & \\
\hline $10^{1}$ & + & + & + & + & + & + & + & + \\
\hline $10^{2}$ & + & + & + & + & - & - & + & - \\
\hline $10^{3}$ & + & + & + & + & - & - & + & - \\
\hline $10^{4}$ & + & + & + & + & - & - & + & - \\
\hline $10^{5}$ & + & + & + & + & - & - & + & - \\
\hline $10^{6}$ & + & + & + & + & - & - & + & - \\
\hline $10^{7}$ & + & + & + & + & - & - & + & - \\
\hline $10^{8}$ & + & + & + & + & - & - & + & - \\
\hline $10^{9}$ & + & + & + & - & - & - & - & - \\
\hline \multirow[t]{2}{*}{$10^{10}$} & - & - & - & - & - & - & - & - \\
\hline & & & coli & & \multicolumn{4}{|c|}{ S. aureus } \\
\hline $10^{1}$ & + & + & + & + & - & - & - & - \\
\hline $10^{2}$ & + & + & + & - & - & - & - & - \\
\hline $10^{3}$ & + & - & + & - & - & - & - & - \\
\hline $10^{4}$ & + & - & + & - & - & - & - & - \\
\hline $10^{5}$ & + & - & + & - & - & - & - & - \\
\hline $10^{6}$ & + & - & + & - & - & - & - & - \\
\hline $10^{7}$ & - & - & + & - & - & - & - & - \\
\hline $10^{8}$ & - & - & + & - & - & - & - & - \\
\hline $10^{9}$ & - & - & - & - & - & - & - & - \\
\hline $10^{10}$ & - & - & - & - & - & - & - & - \\
\hline
\end{tabular}

Rappaport (RP). Enrichment broth for entero bacteria (EE). Selenite-cystine (SC). Broth and tetrathionate broth (TT).

Sign (+) Turbidity with confirmed quantification >10 CFU; Sign (-) No turbidity, or growth in the solid medium

K. pneumoniae were detected in dilution concentrations of $10^{10}$ bacteria per $\mathrm{ml}^{-1}$. This broth permitted growth of S. sonnei in concentration of $10^{1}$ and E. coli up to $10^{2}$ bacteria per $\mathrm{ml}^{-1}$.

In the medium, EE showed high productivity for $S$. sonnei which grew up to concentration $10^{8}$, S. typhimurium grew to concentration $10^{9}$ bacteria per $\mathrm{ml}^{-1}$, and E. coli grew to concentration $10^{8}$ bacteria per $\mathrm{ml}^{-1}$. Selectivity results for Shigella in this medium were comparatively better than in the other broths. S. sonnei and $S$. typhimurium grew to concentration $10^{8}$ bacteria per $\mathrm{ml}^{-1}$; this broth permits recovery of entero bacteria in general, it was shown that this is a selective medium for entero bacteria and it is not differential, which is explained by the high percentages of simultaneous $E$. coli and $S$. typhimurium recovery. The negative control
(S. aureus) did not grow in the media tested.

The TT broth revealed high productivity for $S$. typhimurium $\left(10^{8}\right.$ bacteria per $\left.\mathrm{ml}^{-1}\right)$; however, we also observed growth in high concentrations of $K$. pneumoniae $10^{10}$ bacteria per $\mathrm{ml}^{-1}$.

Finally, it was found that the best broth for $S$. typhimurium recovery, considering tests of pure cultures and tests in mixtures with accompanying microflora, was RP. The EE broth permitted good growth for $S$. sonnei in pure cultures and in mixtures with accompanying microflora. Nevertheless, S. typhimurium was also recovered from this medium. This suggests the usefulness of this medium in simultaneous quantification of these two groups, but it should be complemented with biochemical tests. Since the specificity of RP, such could be used in a second confirmative step in plates of 
Table 3

Selectivity tests for sample bacteria S. typhimurium and S. sonnei

\begin{tabular}{|c|c|c|c|c|c|c|c|c|}
\hline & $\mathbf{R P}$ & SC & EE & $\mathbf{T T}$ & $\mathbf{R P}$ & SC & EE & TT \\
\hline Liquid media & \multicolumn{4}{|c|}{ S. typhimurium } & \multicolumn{4}{|c|}{ S. sonnei } \\
\hline & & & & & & & & \\
\hline 10 & + & + & + & + & - & - & + & - \\
\hline $10^{2}$ & + & + & + & + & - & - & + & - \\
\hline $10^{3}$ & + & + & + & + & - & - & + & - \\
\hline $10^{4}$ & + & + & + & + & - & - & + & - \\
\hline $10^{5}$ & + & + & + & + & - & - & + & - \\
\hline $10^{6}$ & + & + & + & + & - & - & + & - \\
\hline $10^{7}$ & + & + & + & + & - & - & + & - \\
\hline $10^{8}$ & + & + & + & + & - & - & + & - \\
\hline $10^{9}$ & + & - & - & - & - & - & - & - \\
\hline $10^{10}$ & - & - & - & - & - & - & - & - \\
\hline
\end{tabular}

Rappaport (RP). Enrichement for enterobacteria (EE). Selenite-cystine (SC) broth and tetrathionate broth (TT). Sign (+) Turbidity with quantification of desired microorganisms in a range between $10^{6}-10^{8} \mathrm{CFU} / \mathrm{ml}$, and a quantification of undesired microorganisms, without exceeding $10^{4} \mathrm{CFU} / \mathrm{ml}$. Sign (-) Turbidity, but quantifications of desired and undesired microorganisms were within the range or did not grow.

solid medium to separate counts.

Standardization of the MPN. In order to assess the experimental error and define the number of repetitions, tests were conducted in a series of 30 tubes for both microorganisms tested. No significant variability was observed among the repetitions for each treatment and within such, when only one repetition was used in each test. For the model established, it was found that there was good experimental control with $98.6 \%$ reliability for S. typhimurium and $99.3 \%$ for S. sonnei.

Analysis of the most probable number for $S$. typhimurium. Table 4 shows the analysis of the most probable number for $S$. typhimurium and its respective controls (bacterial mix, E. coli, and Staphylococcus aureus). For the interaction hypothesis between concentration and microorganisms, statistic $(\mathrm{F}=12,667)$ found that the interaction between both factors considered is significant on the number of dilutions with $\mathrm{p}=0.0001,(\mathrm{r}=0.986, \mathrm{p}<0.0001)$, which is lower than for the significance ( $\mathrm{p}=0.05)$, for $\mathrm{S}$. typhimurium and for $S$. sonnei, statistic $(\mathrm{F}=22,333)$ found that its effect is significant over the number of dilutions with $\mathrm{p}=0.0001$, $(r=0.993, p<0.0001)$, which is lower than for the significance $(p=0.05)$. Leading us to conclude that there is an interaction between these two dilution and microorganism factors (dependence); hence, it is not possible to analyze them independently. Bearing this in mind, to carry out the comparisons of the principal effects the microorganism level was set and the bacterial concentrations were compared by means of the Duncan multiple comparison test (Post Anova) for the number of dilutions, in the designs established of S. typhimurium and S. sonnei, respectively.

When performing the Duncan multiple-comparison test for S. typhimurium, in concentrations of $10^{1}$ bacteria per $\mathrm{ml}^{-1}$, the result is the same as when simultaneously culturing S. typhimurium, S. sonnei, and S. aureus or E. coli and S. typhimurium. However, differences were found from the dilution of $10^{2}$ bacteria per $\mathrm{ml}^{-1}$, yielding a significance level of $(\mathrm{p}=0.05)$. The inhibition of $S$. typhimurium and the rest of bacteria (E. coli and S. sonnei) in the bacterial mix control may be due to competitive effects among populations for the substrate. We observed that the effect of $S$. aureus is statistically different to the rest of the microorganisms, meaning that the bacteria did not grow in RP, as was expected, because said broth is selective for Gram negative bacteria like Salmonella spp. S. aureus was taken as negative control in the standardization of the MPN.

Upon analyzing concentration $10^{2}$ with level of 


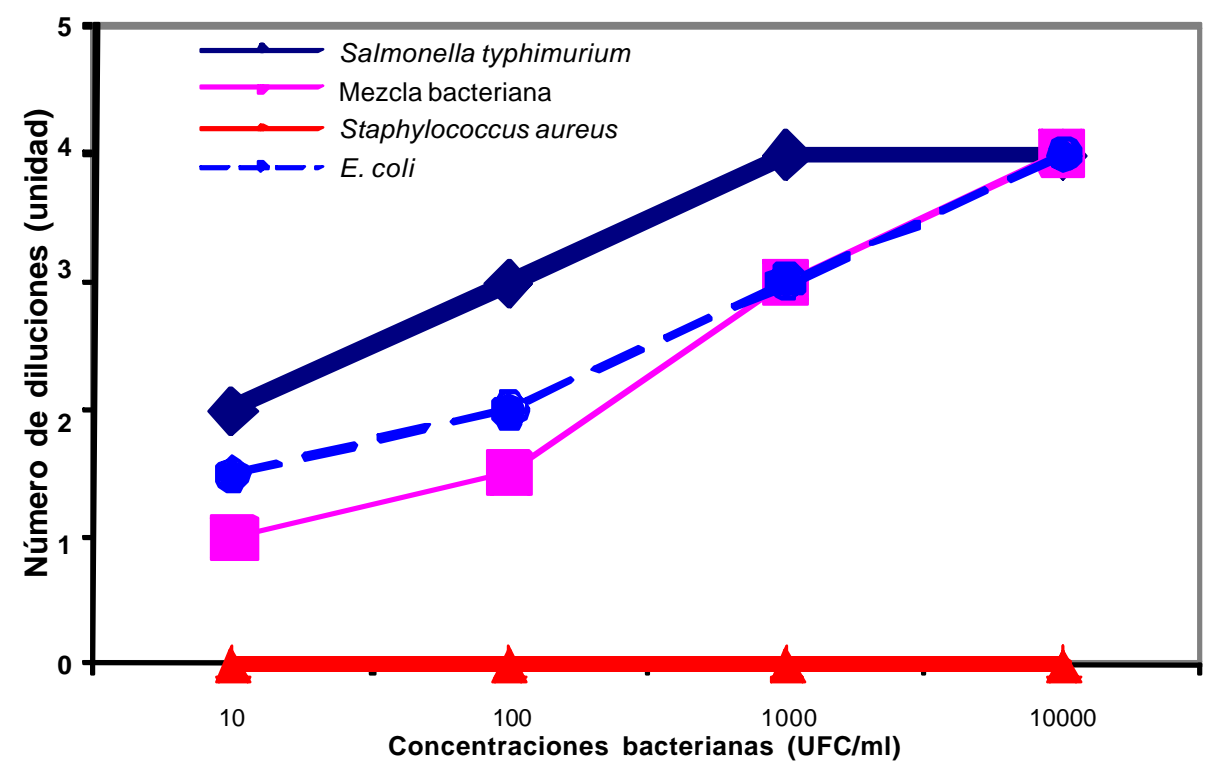

Graph 1. Interaction between bacterial concentration and microorganisms for the number of dilutions for $S$. typhimurium

significance $(\mathrm{p}=0.05)$, it was found that the effect of $S$. aureus is different to that of E. coli, S. typhimurium, and the bacterial mix control. Since it was also established that the bacterial mix control has an equal effect as $E$. coli over the number of logarithmic units from which growth is obtained, i.e., when S. typhimurium is in the microorganism mixture it tends to behave like $E$. coli when it is in pure culture. It was found that this bacterium grows to $10^{3}$ in pure culture, better than when it is part of the bacterial mixture. It is important to highlight that in spite of the differences, S. typhimurium grows well in pure culture or in the presence of the accompanying microflora. The RP broth presents high selectivity to recover S. typhimurium. Results obtained by Lemarchand ${ }^{18}$, in a study conducted in France where a correlation of fecal indicators, Salmonella spp. and Cryptosporidium spp., was carried out in contaminated coastal waters, found that it is feasible to quantify Salmonella spp. with the MPN method using the RP broth, which confirms the results obtained in this study.

For bacterial concentrations at $10^{3}$ and $10^{4}$, it was not necessary to carry out the multiple comparison test; since no difference was observed in the effect among $E$. coli, S. typhimurium, bacterial mix, and S. aureus.

In the concentration at $10^{3}$, the microorganism mix, as well as $E$. coli grows three logarithmic units; different to $S$. typhimurium, which grows four logarithmic units. This result is very similar to what was obtained in the concentrations at $10^{1}$ and $10^{2}$. S. aureus did not grow because it is Gram positive.

In the concentration at $10^{4}, S$. typhimurium grew four logarithmic units, both in pure culture as when it was part of the mix, E. coli also grew four logarithmic units. That is, there is a direct relationship between the dilution used and the growth obtained (Graph 1, Table 4). As in the previous concentrations $S$. aureus did not grow in equal manner as in the previous concentrations.

We can conclude that the RP broth permits good recovery of $S$. typhimurium; coinciding with Moreno et al., who used the RP broth as enrichment broth for Salmonella spp. from samples taken at a secondary treatment plant of residual waters. This pre-enrichment increased the number of viable cells detectable with in situ hybridization ${ }^{19}$.

Analysis of the most probable number for $S$. sonnei. The analysis for the most probable number for $S$. sonnei is presented in Tables 6 and 7. As for $S$. typhimurium, its respective controls are presented: $E$. coli, bacterial mix, and Staphylococcus aureus.

Analysis of the model of the S. sonnei design. For all bacterial concentrations from $10^{1}-10^{4}$, it was not necessary to carry out the multiple comparison test, 


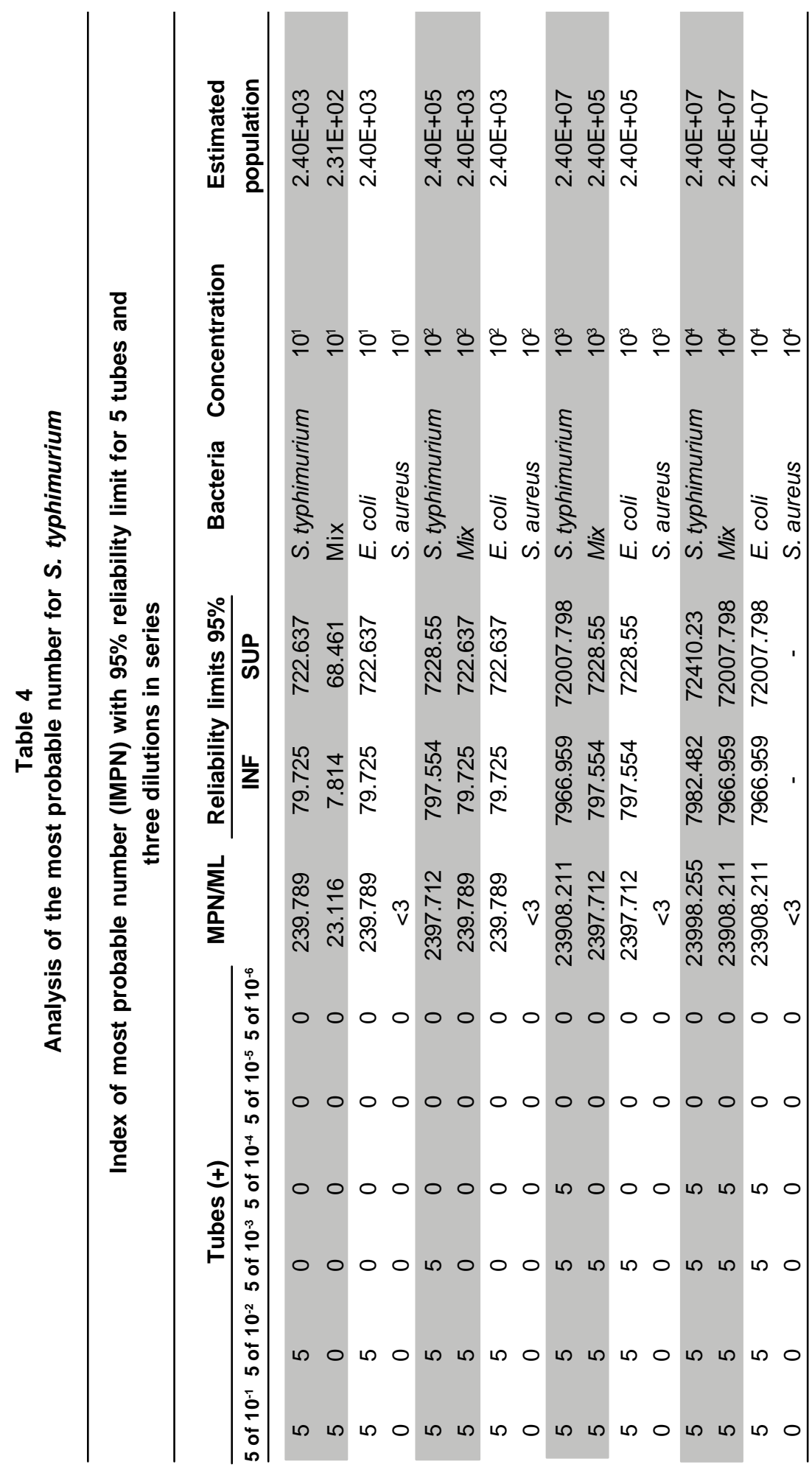

because there is no difference in the effect of $E$. coli, $S$. sonnei, mix of species, and $S$. aureus. S. sonnei, in EE broth, like $S$. typhimurium in RP, grows better in pure culture than when it is accompanied by other species. The mixture of microorganisms and E. coli show the same behavior, requiring the same dilutions to grow in EE. The $S$. aureus control did not grow (Figure 2). Our results confirm those of Warren ${ }^{20}$, who compared conventional culture methods and the polymerase reaction (PCR) to detect Shigella spp. in tomato surfaces, finding that the EE broth recovers Shigella spp. very well from high concentrations at $10^{5}$ to vary low ones at $10^{1}$.

There is no variation between the mixed culture and E. coli; the quantification is proportional to the dilution of origin (Graph 2, Table 5).

S. sonnei grows better in pure culture; this result was expected because bacteria in mixed culture a) can compete for the nutrients, and/or b) their metabolic products inhibit growth. The concentrations at $10^{1}$ and $10^{2}$ of $S$. typhimurium are detected in the RP broth, but when such bacterium is in a mixed culture, S. sonnei, $S$. typhimurium, and E. coli) it is inhibited. E. coli grows well in the RP broth, even if inoculated at low concentrations of $10^{1}$ and $10^{2}$. S. sonnei tends to grow in greater concentrations than $E$. coli in pure culture.

The EE broth permits good 
Table 5

Relation between CFU and detection limit in Rappaport (Merck) liquid medium

\begin{tabular}{lccll}
\hline & \multicolumn{3}{c}{ CFU/ml } \\
\cline { 2 - 5 } & $\mathbf{1 0}$ & $\mathbf{1 0}^{\mathbf{2}}$ & $\mathbf{1 0}^{\mathbf{3}}$ & $\mathbf{1 0}^{\mathbf{4}}$ \\
\hline Salmonella typhimuriumserovariety & 0.01 & 0.001 & 0.0001 & 0.0001 \\
E. coli & 0.5 & 0.01 & 0.001 & 0.0001 \\
S. aureus & $\mathrm{ND}$ & $\mathrm{ND}$ & $\mathrm{ND}$ & $\mathrm{ND}$ \\
BacterialControlMix & 0.1 & 0.5 & 0.001 & 0.0001 \\
\hline
\end{tabular}

ND: Not detectable

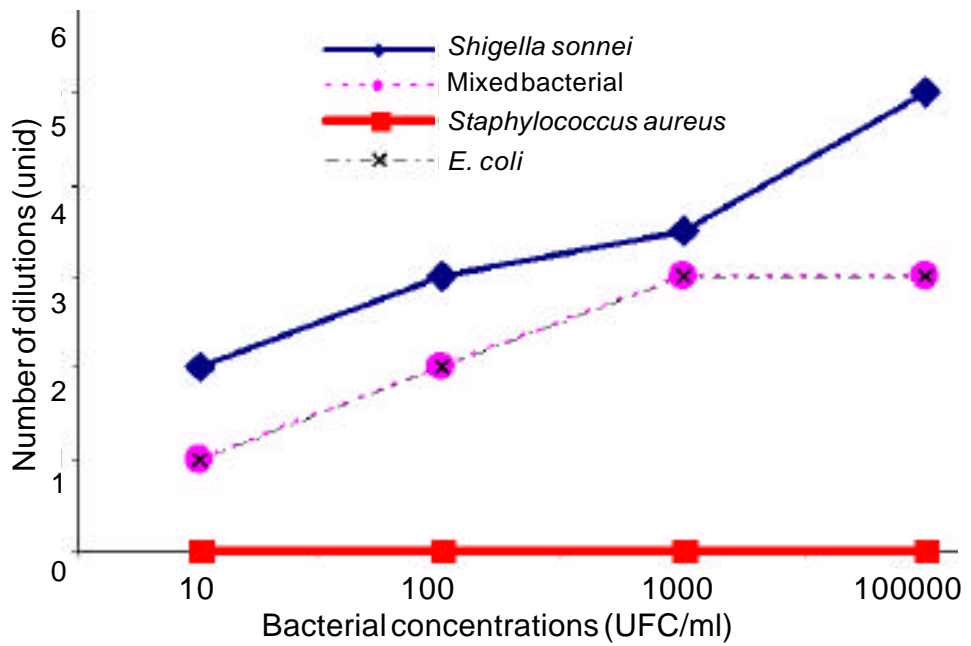

\section{Graph 2. Interaction between bacterial concentration and microorganisms for the number of dilutions for $S$. sonnei}

growth of the $S$. sonnei bacterium, both in pure culture and mixed culture. Bacterial identification was verified via manual biochemical tests (BBL). S. aureus did not grow in this medium.

When conducting the MPN in EE broth with concentration at $10^{1}$ of $S$. sonnei we found that said bacterium grows from two dilutions, in the standardization of the MPN when the bacterium is part of the mixture (S. sonnei, E. coli, and S. typhimurium) it only grows from the first dilution, similar to that found withE. coli. When $S$. sonneiwas inoculated from the concentration at $10^{2}$ in EE broth, it grew by 3 logarithmic units; when the bacterium is in a mixed culture, it grows by two logarithmic units, as doesE. coli. When conducting MPN with the concentration at $10^{3}$ of $S$. sonnei, it was found that it grew by 3.5 and 3 logarithmic units in pure culture and in mixed culture, respectively, as does E. coli. When MPN is conducted with a concentration at $10^{4}$, it was found that $S$. sonnei grows by 5 logarithmic units; while in mixed culture it grows by 3 logarithmic units.

\section{CONCLUSIONS}

The best results for recovery of different cellular densities of $S$. typhimurium were obtained in the Rappaport broth from Merck (RP) and for S. sonnei in enriched broth for entero bacteria from EE (Oxoid). For standardization tests, the Duncan multiple tests permitted establishing the differences in the recovery of the microorganisms tested for the different cellular densities; greater recovery was observed for all cellular densities in pure cultures and significant differences were established with their recovery in the presence of other bacteria species. Given that in nature and in real samples there is also the coexistence of a diversity of bacteria, we should expect relationships similar to competition and/or inhibition. However, even if the bacteria are accompanied, they manage to grow in minimal concentrations in the respective broths.

The S. sonnei and S. typhimurium bacteria could be detected and quantified in their respective $\mathrm{EE}$ and $\mathrm{RP}$ broths when residual and domestic waters have been treated for disinfection with UV, processes of advanced oxidation, Ozonization, and SODIS, which are methods that can generate viable nonculturable bacteria due tooxidativestress. Notwithstanding, given that the EE broth (Oxoid) permits good recovery of $S$. sonne $i$-both in pure culture as in bacterial mixtures, but it is not 


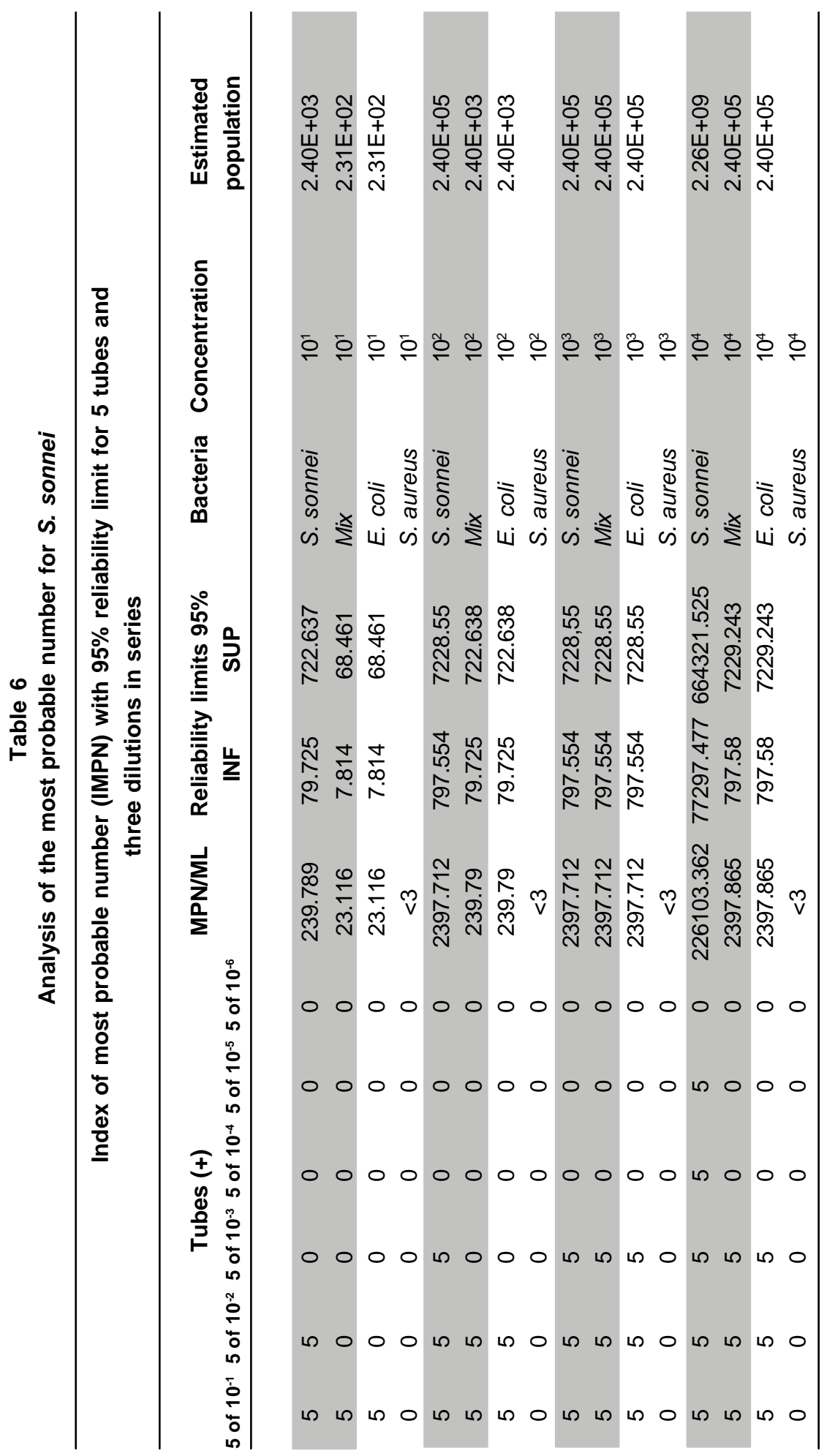

selective for S. typhimurium. This medium can be used as a differential always accompanied by confirmation tests in solid media.

The MPN is a method of easy application and extensive use, which can be used based on the results to economically and reliably quantify $S$. typhimurium and S. sonnei in disinfection processes.

Conflict of interest. None of the authors has conflicts of interest related to this study.

\section{ACKNOWLEDGMENTS}

This work was funded by the BIOSOLAR-DETOX project within the framework of the EPFL SUIZA-UNIVALLE agreement; the authors express special gratitude to MSc Miriam Astudillo and to statistician Diego Gómez for their support; and fortheirscientific contributions in the development of tests to: Danny Mercedes Acevedo, Leidy P. Bedoya, and Luis E. Mora; and in general to the GAOX group for their contributions in the discussion.

\section{REFERENCES}

1. WHO, OECD. Assessing microbial safety of drinking water. London: IWA Publishing; 2003.

2. Reiff FM. El estado de la desinfección del agua potable en América Latina y el Caribe.En: Organización Panamericana de la Salud. La calidad del agua potable en América Latina: Ponderación de los riesgos microbiológicoscontralos ries- 
Table 7

Relation between CFU and limit of detection in the EB liquid medium

\begin{tabular}{lcccc}
\hline & \multicolumn{4}{c}{ CFU/mI } \\
\cline { 2 - 5 } & $\mathbf{1 0}$ & $\mathbf{1 0}^{\mathbf{2}}$ & $\mathbf{1 0}^{\mathbf{3}}$ & $\mathbf{1 0}^{\mathbf{4}}$ \\
\hline S. sonnei & 0.01 & 0.001 & 0.0001 & 0.00001 \\
E. coli & 0.1 & 0.01 & 0.001 & 0.001 \\
\hline S. aureus & $\mathrm{ND}$ & $\mathrm{ND}$ & $\mathrm{ND}$ & $\mathrm{ND}$ \\
Bacterial ControlMix & 0.1 & 0.01 & 0.001 & 0.001 \\
\hline
\end{tabular}

\section{ND: Not detectable}

gos de los subproductos de la desinfección química. Washington, DC: ILSI Press; 1996. p. 101-14.

3. World Health Organization. Guidelines for drinking-water quality-recommendations. Geneva: WHOPress; 2006.

4. Ashbolt NJ. Risk analysis of drinking water microbial contamination versus disinfection by-products (DBPs). Toxicology. 2004; 198: 255-62.

5. Malato S, Fernández-Ibáñez P, Maldonado MI, Blanco J, Gernjak W. Decontamination and disinfection of water by solar photocatalysis: Recent overview and trends. Catalysis Today. 2009; 147: 1-59.

6. Litter MI. Tecnologías avanzadas de oxidación: Tecnologías solares. In: Blesa MA, Gálvez JB (eds).Tecnologías solares para la desinfección y descontaminación del agua.Provinciade Buenos Aires: Universidad Nacional de San Martín, Editorial Escuela de Posgrado UNSAM;2005. p. 67-70.

7. Yokomaku D, Nobuyasu Y, Masao N.Improved direct viable count procedure for quantitative estimation of bacterial viability in freshwater environments. Appl Environ Microbiol. 2000; 66: 5544-8.

8. Maness P-C, Smolinski S, Blake DM, Huang Z, Wolfrum EJ, Jacoby WA. Bactericidal activity of photocatalytic $\mathrm{TiO}_{2}$ reaction: Toward an understanding of its killing mechanism. Appl Environ Microbiol. 1999; 65:4094-8.

9. Torres W, Invernizzi M, Sanabria J, Dierolf C, Latorre J, Pulgarín C. Evidence for recovery of bacterial cell count after treatment of $\mathrm{E}$. coli with $\mathrm{TiO}_{2}$ photocatalysis. Toronto: 5 th International Conference on $\mathrm{TiO}_{2}$ Photocatalytic Purification and Treatment of Water and Air; 2000.

10. Castillo JA, Sanabria J, Wist J, Pulgarín C. Evaluation of the photocatalytic treatment for the removal of pathogenic agent from different biological wastewater treatment effluent.WEMS. 2005; 1: 139-54.

11. Ministerio de la Protección Social. Vigilancia en red de Salmonella spp., Shiguella spp. y Vibriocholerae, Colombia 2000-2001 (fecha de acceso 18 de febrero del 2005). URL available in: www.sivigila.com
12. Josset S, Keller N, Lett MC, Ledoux MJ, Keller V. Numeration methods for targeting photoactive materials in the UV-A photocatalytic removal of microorganisms. Chem Soc Rev. 2008; 37: 744-55

13. ISO/TS 11133-2. Microbiology offood and animal feeding stuffs. Guidelines on preparation and production of cultura media. Part 2. Practical guidelines on performance testing of cultura media. Brussels: Cen; 2002.

14. FAO. La garantía de la calidad en el laboratorio químico de control de los alimentos. Manuales para el control de la calidad de los alimentos. Alimentación y Nutrición 14/14. Roma: FAO; 1996. p. 39-72

15. FAO.La garantía de la calidad en el laboratorio microbiológico de control de los alimentos. Manuales para el control de la calidad de los alimentos. Alimentación y Nutrición 14/12. Roma: FAO; 1992.p. 58-60; 70-2.

16. Secretaría de Medio Ambiente para el Desarrollo Sustentable. Norma oficialmexicana nom-004-semarnat-2002, protección ambiental-lodos y biosólidos-especificaciones y límites máximos permisibles de contaminantes para su aprovechamiento $y$ disposición final. (fecha de acceso 25 de enero del 2005). URL disponible en: http://www.semades.jalisco.gob.mx

17. Briones AMJr, Reichardt W. Estimating microbial population counts by 'most probable number' using Microsoft excel®.J Microbiol Meth. 1999; 35: 157-61.

18. Lemarchand K, Lebaron P. Occurrence of Salmonella spp. and Cryptosporidium spp. in a French coastal watershed: Relationship with fecal indicators.FEMS Microbiol Lett. 2003; 218: 203-9.

19. Moreno Y, Montes R, Hernández J, Jiménez A. Detección rápida y especifica de Salmonella en muestras de agua mediante hibridación in situ (FISH). Sevilla: Congreso Iberoamericano sobre Seguridad Alimentaria; 2006.

20. Warren BR, Parish ME, Schneider KR. Comparison of conventional culture methods and fta filtration-nested PCR for the detection of Shigella boydii and Shigella sonnei on tomato surfaces. J Food Protect. 2005; 68: 1606-12. 